\title{
SCIENTIFIC PRODUCTION AND SCIENTIFIC QUALIFICATION EVALUATION: SOME PROBLEMATIC ISSUES
}

\author{
Vincentas Lamanauskas \\ University of Siauliai, Lithuania
}

\begin{abstract}
In recent years, there has been a lot of discussion about the quality of studies and, in general, about the education quality. As we know, the quality of studies depends not only on level of motivation and cleverness of students, how well developed the infrastructure of institutions is and so on. Probably, even more, the quality of studies depends on scientific pedagogical personnel, the one, which directly determines the preparation of a future student. This article deals with problems related to the scientific production and scientific qualification evaluation. Also the article describes some characteristics of researchers and scientific production in general.

Science, in some sense, has strong immunity, but in recent years, it has been rapidly weakened both internally and externally. Of course, we have to believe, that universities will understand that it is firstly on them to save and strengthen both quality of activities and prestige and develop real but not demonstrated science. Europe "has been having a headache" for a long time thinking how to withstand ever - strengthening competition with such regions as North America (especially USA), South-east Asia and so on.
\end{abstract}

Key words: scientific activity evaluation, academic staff, scientific production, universities.

\section{Introduction}

Scientific activity evaluation is becoming problematic not only in Lithuania but also in many other countries nowadays (Lamanauskas, 2009). Various higher education and scientific research system reforms are taking place not in one country. It is especially characteristic to Central and Eastern Europe countries, which have been under Eastern world (Russia) influence for a long time. Scientific production and scientific activity evaluation, on the whole, in essence was alienated from standards and criteria formed in Western word. Science and study reform being carried out in Lithuania comprises not only structural changes but also qualitative change of scientific activity. The role of science theory becomes very important. When we are talking about scientific production (mostly about various publications) evaluation, it is more purposeful to analyse the problems of scientometrics. The essence and basis of scientometrics is quantitative indicators. Though, more and more attention has been devoted to qualitative evaluation in recent years, however, quantitative indicators remain universal and generally acknowledged. One of the newest publications in this field is P. Vinkler's (2010) book about quantitative scientific publications' evaluation methods. In this book such questions as the classification of evaluative scientometric indicators, the growth of the number of scientific publications, journal citation index (Garfield indicator), scientific information ageing, scientometric indicators for evaluation of publications, scientific information institutionalisation and other are analysed. The appearance of this book actualises the appliance of quantitative scientometric parameters in the evaluation of scientific production and the work of institutions carrying out scientific activity as well. It is obvious, that quantitative indicators are based on special mathematic calculations, which at first sight is not being questioned. However, the opponents are constantly warning that there happen to be more cases of scientific work fabrication and falsification (Fa- 
nelli, 2009). International association of mathematicians carried out a research Citation statistics (Adler, Ewing, Taylor, 2008). It was revealed in the report that world academic society should not exaggeratedly rely only upon bibliometric evaluations of scientific works. In the collision of quantitative and qualitative evaluation various heavily solved contradictions appear. In many countries not only financing of scientific researches but also academic career is being closely related to quantitative evaluation of scientific production. Various evaluation deviations appear in such environment, negative competition (pseudocompetition) flourishes. This is taking place even in the countries having strong science positions, e.g. USA (Anderson, Ronning, De Vries, Martinson, 2007).

It is obvious, that plenty of science work ranking and evaluation systems exist. On the other hand, it is doubtful if any of them is suitable for the whole science direction, science work and university type variety or for other evaluation purposes. In spite of various contradictions, evaluation systems have to be improved, elements, having negative influence have to be sought to eliminate. In general sense, academic activity consists of three components: teaching, scientific researches, study organisation. Every component is undoubtedly important, though we can acknowledge the fact that scientific researches in many countries are most important, first of all, in the sense of scientific career. In other words, scientific researches for the member of academic society, seeking academic career, become obligatory. In spite of this, the evaluation of scientific production remains controversial and impact factor is not the only suitable criterion in the evaluation (Gómez-Sancho, Mancebón-Torrubia, 2009).

Thus, the object of this analysis is the evaluation of scientific production and scientific qualification. The aim of analysis is to reveal the main scientific production and scientific qualification evaluation aspects and to discuss international practice in this sphere. The methods applied are: scientific information source analysis, document analysis, meta-analysis, interpretation method.

\section{Scientific Production Evaluation in Lithuania}

One of important science evaluation fields is scientific publications. During the whole period after 1990, clear and consistent system never settled in Lithuania. Every year science production evaluation methodics are being changed. The essential question is what direct influence is of such evaluation on scientific researches and their dispersion. The year 2010 is important in this sense that the term settled in Lisbon strategy in 2000 for implementation of various tasks expires. In the mentioned strategy an ambitious aim was raised - to turn Europe into the most competitive world region by the year 2010. It was foreseen to allot even $3 \%$ of European Gross domestic product for scientific researches. Now it is already clear that these goals will not be achieved and, on the whole, it is not clear when they will be achieved.

In the summer of 2009 Lithuanian higher institutions got a new scientific production evaluation methodics. To be more precise, the new methodics was confirmed by Lithuanian Republic Minister of Education on $29^{\text {th }}$ June, 2009, by the order No. ISAK-1321. The mentioned document regulates the evaluation of science works of various science fields. The evaluation of physical, biomedicine and technology science works differs greatly from the social and humanitarian sciences work evaluation. Traditionally, this field science production evaluation is much clearer, has more clarity, more tangible criteria and so on. Whilst humanitarian and social science field science work evaluation is much more doubtful. Most of this field works are being published in the local market and do not reach the wider circle of consumers. The other thing is that the majority of these publications are in Lithuanian language. Yes, that is also very important developing Lithuanian science, especially humanitarian sciences. But, here also a simple rule is valid - science is not national, it is and has to be international. I think, that it is necessary to encourage Lithuanian scientists and researchers to publish more as possible of 
their works in the international publications, not necessarily in the most prestige ones. In this way important competences are being acquired, a normal idea and information interchange is taking place. This especially is common in the field of humanitarian and social sciences. Such publications should be correspondingly evaluated.

The first and the second level science works are distinguished in the mentioned methodics. The first level science works, according to methodics, are considered those highest level scientific researches and experimental works which are acknowledged as such by the institutions themselves and in respect of quality are evaluated by Lithuanian Science Council experts. The problem of objectivity of evaluation arises here, because financing of a higher school in a greater part depends on scientific production quantity. Applicable, educational and other works of a similar purpose can be distinguished as the first level works, which are not publications. Finally, evaluation quality directly depends on current academic culture level, academic ethics standards being formed and so on. On the other hand, without experts help, it is impossible to ascertain the significance of production unit according to formal criteria. Independent expert evaluation is really a gratifying thing. But the problem is expert's impartiality, competence and objectivity.

It is also interesting, that it is suggested to accept not all B level production if it is too much of it comparing with A level production. The conditions of acceptance depend on the science field. The contradiction occurs between scientific researches and also between the growth of publications and limitations applied for the publication quantity. Another problem is that repeated science publication evaluation is often groundless. First, if science work is published in a serious international (or in a national) science publication, it is valuable in itself. It remains to agree about formal evaluation procedure, but expert evaluation is completely not necessary. For example, if you give a prepared script of an article to science journal editorial staff, it is evaluated by at least two independent reviewers. Thus, is it sensible to carry out expert evaluation once again? Not less important thing is electronic source (publication) evaluation. More and more scientific methodical information is announced on the internet and not necessarily according to the same rules and standards which are common to traditional (printed) information presentation form. And such information will only increase. In many places universal evaluation instruments are being used, which are not directly meant for evaluation of scientific information, but could be adapted not heavily. One of such instruments is Google Page Rank Checker. Google Page Rank can be successfully applied not only relatively to evaluate internet pages but scientific publications as well.

Another groundless thing also not once discussed in the press is joining social and humanitarian sciences into one group. This means that the same methodics attitudes will be applied for both fields. The question is, how to compare according to the same methodics, let's say, economics and linguistics works?

A new evaluation methodics editorship was confirmed by Lithuanian Republic Minister of Education and Science on $10^{\text {th }}$ July, 2010, by the order No. V-1128. In the methodics it is stated, that science works of Humanitarian and Social sciences are evaluated by expert group formed by Lithuanian science council Humanitarian and Social sciences committee. Science works of Physical, biomedicine and technology sciences are evaluated by expert group formed by Lithuanian science council Nature and technical sciences committee. A principle of publication division into two levels remains in the new methodics. The new is, that selected first level works are evaluated by experts and for the second level works formal evaluation is applied. The second level work units are evaluated by points (Science and study......., 2010). 


\section{Science Production and Science Qualification Evaluation: International Context}

\section{Science Journals}

Undoubtedly, the main science information source is science journals. It is well known for everybody (for the scientists first of all) that science journal system consists of two levels. For the first level belong so-called prestige science journals (primary research journals). Journals, in which first level works are indexed or summaries are announced, form the second level (secondary journals). Recently, more than 75000 first level journals have been counted. About $10 \%$ is controlled by so-called scientific information institute (Thomson Reuters). As scientists notice, journals which do not get into that system are considered marginal editions, and, of course, less meaningful (Toshev, 2008). Another important science evaluation indicator (scientometric parameter) which is almost universally agreed, is so-called Impact factor. Let's remember that IF was implemented by E.Garfield (1972). Of course, it is not the only one parameter. The other parameters are widely applied on the international level as well, because it is acknowledged that scientific activity, scientific creativity is a cumulative phenomenon. Therefore, close to IF occur such parameters as efficiency parameter (efficiency factor), productivity parameter (factor of productivity), usefulness parameter (factor of utility). Very important is so-called citation index (Science Citation Index - SCI). Despite of its importance and significance, even this parameter received a lot of reasonable critics. Researchers notice that only complex approach guarantees stability and steadiness of the science process. And this is very important for the harmonious science development. Some countries have created or successfully are creating national scientific work citation systems. For example, Russia has such a system as a certain counterbalance against foreign systems (rus.: Российский индекс научного циитирования). Speaking about Lithuania, creation of such national system would be useful for the country itself first of all, because it would only make general picture of science level more accurate. It is still important because evaluation in itself in a greater part is connected with the financial resource distribution for science and study institutions.

\section{Reviewing}

Another essential thing is secret, impartial science work evaluation (reviewing). In other words, it is called anonymous review (peer review). Usually, prestige science journals take care of their reputation very much and are interested in clear evaluation. Most frequently, one science work is evaluated by two independent assessors (peers). So-called one-sided blind scientific reviewing is being practiced, when only a reviewer knows author's identity and double-sided blind scientific reviewing when both reviewers and authors remain unknown to each other. Both approaches have their own advantages and disadvantages. The third approach is also applied when the author knows who the assessor of his work is. The truth is that on a so-called micro level, contradictions inevitably exist among authors, assessors and editors of publications. However, the application and co-ordination of various evaluation approaches guarantees the highest possible evaluation clarity. The question being discussed (on an international level) is reviewer selection. It is obvious, that the reviewer has to be an expert in a concrete field. Despite of the reviewer's competence, not a small probability exists that a reviewer will be partial. On the other hand, the reviewer has got a very big responsibility seeking not to let poorly carried out researches and plagiarisms get into the circulation of science. A universal rule is valid that authors must know very clear arguments, if the reviewers negatively evaluate works (articles or projects). There are two types: ex post reviewing (e.g., articles) and ex ante reviewing (e.g., projects). The first way is less risky and the second is rather risky. Researches show 
that partiality usually exists: with respect to women, with respect to younger researchers and with respect to minority.

In any case international practice is diverse and abundant. Any evaluation of science works as well as their preparation are closely connected both with general and science ethics.

\section{International Experience}

Taiwan. The evaluation system for the scientific production is strong enough in Taiwan. Each faculty member needs to be evaluated on a university level every four years. If someone fails the evaluation (including scientific production, services and teaching), he/she has to be evaluated once again next year. Two failures in a row will result in losing a job. On a national level, scientific production takes about $50 \%$ of the grade while applying for research grants. Every five years a government foundation is evaluating the performance of a department or faculty in general (including scientific production, services and teaching).In the case of failure the department can be forced to close. Taiwan has an adopted USA system for the academic promotion. Someone with a $\mathrm{PhD}$ degree can be hired as an assistant professor. After three years he/she can apply for an associate professor, after three more years for a full professor. Scientific production is highly related to the success of promotion. There is no fixed number of papers. Three outside reviewers in the field are examining the quality of papers and give credits. In recent years the standards of promotion are getting higher. Only publications in highly cited international journals will be counted. For most universities, an assistant professor will lose his/her teaching job if he/she cannot be promoted to an associate professor in six years period.

Turkey. The main problem is to become an associate professor. In order to be an associate professor you have to apply to Higher Education Council (HEC) for the examination (http://www.osym.gov.tr). There are some requirements for application:

- foreign language examination: it is done by OSYM on a national level. The barrier score is 65 .

- a lot of academic staff are waiting for this because it is not so easy to get the score 65. This is one of the main problems.

- she/he has to publish at least one paper in Thomson Reuters journals. It must be single author's paper.

- some extra papers on a national level.

If she/he corresponds to the requirements above, he/she is sending their publication files to 5 professors. The names of professors are sent to an applicant by HEC. They examine the files and they write a report to HEC. If 3 (at least) of the professors approve of the applicants suitability for an associate professor's position, then an oral examination is being done. If an applicant passes an oral examination, he/she receives an associate professor's title from HEC. After that he/she has to find a position at the university. It is not so difficult because at this time all universities in Turkey have enough associate professor's positions. After 5 years of work in the position of an associate professor, the applicant can apply for a professor's position according to the university, but it is not difficult as compared with associate professor's position. In general, approximately each professor receives full professor position after 5 years. Associate professor (docent) is valid as a title and as a position. It is possible to use this title even if a scientist has no connection with the university. In order to use professor (full) title, a scientist has to get a position at the university. Otherwise, it is not possible.

The evaluation is very problematic and complex in Turkey. Mainly it depends on the university. For example, in state universities there is no clear evaluation system. The docent 
and professor positions are permanent jobs in universities. There are some exceptions. For example, at the Middle East Technical University and Bogazici University the academic staff is evaluated every semester using some questionnaires filled by students and their academic publications.

Malaysia. In Malaysia each university has its own evaluation system despite the fact that guidelines are quite similar. There is no state evaluation. The state grants the university financial aids (research, etc.) and grades universities according to university performances as a whole. The point system is used for evaluation procedure. The main requirements if he/she wants to become professor (full) are: research and publication with international refereed journals, with distinguished scholarship prominence or achievement in a specialized field. For the associate professor - minimum (3-5) years of tenureship, publications in local and /or international journals, conduct researches in specialized fields.

Table 1. The main elements in the application form for promotion to the post of professor at the Science University of Malaysia.

\begin{tabular}{|c|c|}
\hline Elements & Notes \\
\hline A. Personal Details & $\begin{array}{l}\text { Based on the performance listed in the curriculum vitae, please } \\
\text { outline the achievements in scholarship (approximately half a page } \\
\text { for each category) and provide a self-evaluation on your best } \\
\text { contributions. It should not include information directly mentioned } \\
\text { in the curriculum vitae. (Please refer to the guidelines). }\end{array}$ \\
\hline $\begin{array}{l}\text { B. Summary of } \\
\text { Achievements } \\
\text { 1. Research and } \\
\text { Publication. } \\
\text { 2. Teaching and } \\
\text { Supervision. } \\
\text { 3. Academic Recognition } \\
\text { and Leadership. } \\
\text { 4. Consultancy. } \\
\text { 5. Service to the } \\
\text { university. } \\
\text { 6. Service to the } \\
\text { community. }\end{array}$ & $\begin{array}{l}\text { 1. Please summarize how your research outcomes/activities and } \\
\text { publications have contributed to the development and enhancement } \\
\text { of knowledge } \\
\text { 2. Please provide an outline of your activities related to curriculum } \\
\text { development, innovative contributions, creative teaching } \\
\text { methodology, as well as your abilities and accomplishments in } \\
\text { student supervision. } \\
\text { 3. Provide an outline of your strengths in your specific fields and the } \\
\text { academic community perception of you. } \\
\text { 4. Comment on your achievements and contributions in terms of } \\
\text { quality, importance and outcomes, as well as the client's/society's } \\
\text { perception of your consultancy. } \\
\text { 5. Comment on your main role(s) and contributions in the drafting, } \\
\text { planning and implementation of academic, administration and } \\
\text { management policies at Unit/ Department/Section/University Level. } \\
\text { 6. Comment on your main role(s) and contributions towards society. }\end{array}$ \\
\hline C. Summary & $\begin{array}{l}\text { Provide reasons that justify your application for promotion to } \\
\text { Professor (maximum of one page). }\end{array}$ \\
\hline $\begin{array}{l}\text { D. Comments by Head of } \\
\text { Department }\end{array}$ & \\
\hline $\begin{array}{l}\text { E. Nomination of External } \\
\text { Assessor }\end{array}$ & $\begin{array}{l}\text { The candidate is allowed to nominate } 3 \text { External Assessors (full } \\
\text { Professor) from within the country/ abroad. The External Assessors } \\
\text { must be in the related field. }\end{array}$ \\
\hline
\end{tabular}


Each of these blocks (elements) are disintegrated in detail into concrete criteria, which are evaluated by grades. The system is rather exhaustive, clear, various academic activities are evaluated.

Czech Republic. In Czech Republic professor's titles are granted by the president of the country. Usually twice a year about 40 professors' names are granted in all science branches. This is valid for all country universities. A very similar order is in Slovakia and it is understandable, because both countries have a common history. Professor's position occupation is not an easy thing here. First of all, it is a long process. First, the candidate has to be doctor of sciences (so-called Ph.D or according to their system CSc.). Another requirement is to be docent (in other words, associate professor). The third requirement is to attain habilitation. Habilitation work is being written or monograph is being issued. It is necessary to read so-called habilitation report for university or faculty science council. Also, other important works are being required - publications, taking part in international and national projects and so on. It is interesting, that it is required to hand in not less than two recommendations from scientists acknowledged on international level and also person's scientific work evaluations-reviews. Thus, after going through mentioned and not mentioned procedures university rector proposes a dossier to an appropriate ministry and ministry after analysing papers, proposes a suggestion to the President of the Republic. It is also important, that not every university can perform such a procedure. University must have special accreditation for carrying out the process of professorship.

Bulgaria. In Bulgaria the requirements are also rather strict. Let's say, wishing to become a professor in physical sciences field you must have the second science degree (DSc), more than 50 articles in science journals, from which not less than 25 have to be in publications with Impact Factor. It is even necessary that the works were cited in scientific literature by other authors not less than 50 times. Besides, final solution is accepted by SAC (Senior attestation commission). Recently a new Academic career law is being discussed in Bulgarian parliament, in which the requirements are made softer, e.g., $\mathrm{PhD}$ degree is foreseen, managing doctorates, original contribution to university development, SAC is being refused and so on. However, academic society contradicts very much to such requirement weakening. A common thing is seeking to keep rather high but flexible requirements.

Brazil. Scientific production evaluation system exists in Brazil. Wishing to get financial support for researches, it is necessary to do publication in the international press actively. Every university department prepares reports about scientific production. Over the last several decades Brazil made a big jump in science research development, first of all, due to rational science policy. Article preparation and publication in English are encouraged. Expert commissions are formed for evaluation. The attitude is being hold to keep balance between the higher level publications and local publications. Taking a position at universities, scientific production is the most important. University financing is closely related to scientific production. Two main stages are distinguished in Brazilian science strategy: the first, by all possible means to increase Brazilian contribution on an international level, the second, to move to qualitative scientific production evaluation as well. Science journals are evaluated according to following most important criteria: Are they included into database; The quality of articles (scientific character, correspondence to thematic, the number of original articles, content newness and so on); The quality of editorial colleges; Article selection procedures; The variety of authors; The dissemination of the journal; Journal indexation. All Brazilian journals are classified. QUALIS/CAPES model is applied (Coordination for Higher Level Education Improvement /Coodernação de Aperfeiçoamento de Pessoal de Nivel Superior). They are grouped into 7 strata: A1 (the highest valuže - 100), A2, B1, B2, B3, B4, B5 and C (the lowest value).

Avery significant is so-called SCIELO project, the main aim of which is Brazilian science journals' classification, evaluation and so on. 


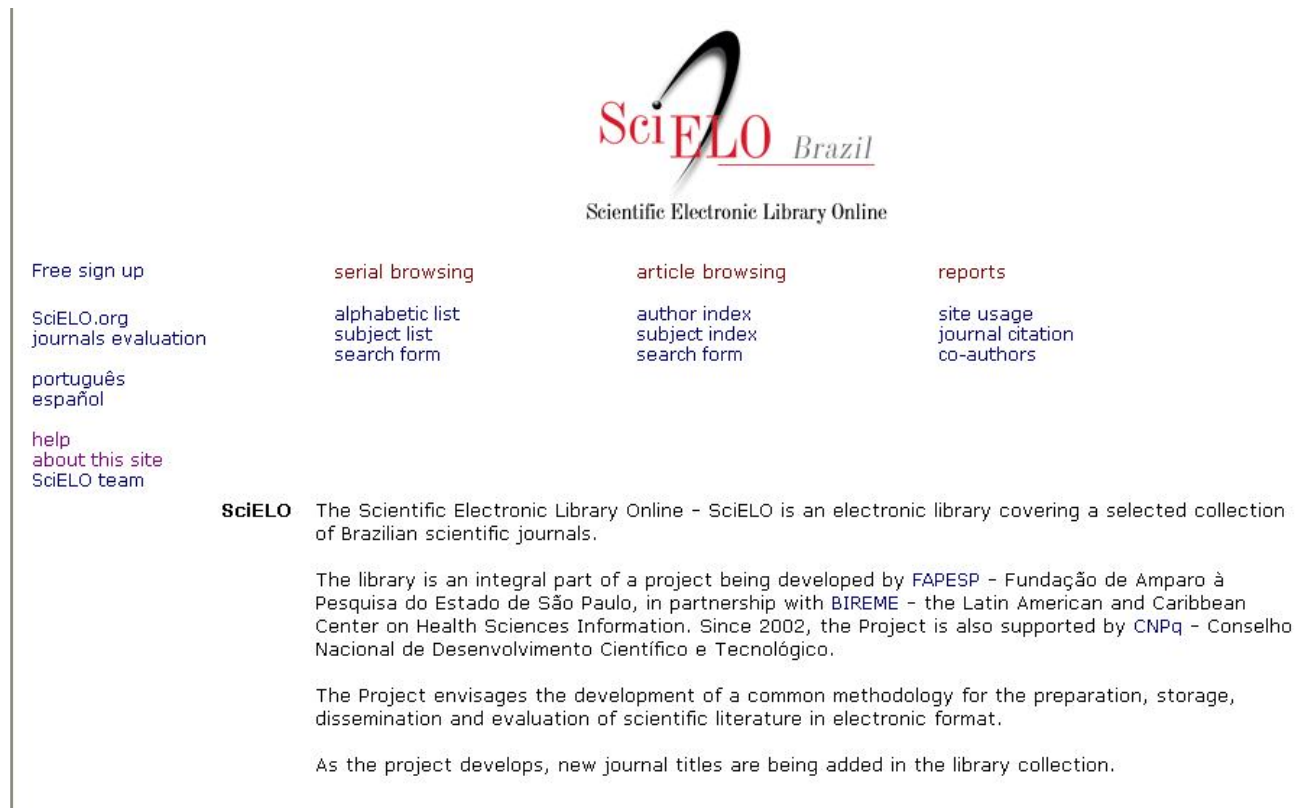

\section{Figure 1. The website of SCIELO project.}

SCIELO raises rather high requirements. In order the journal was included, the following is being evaluated:

- scientific character(content) - only original articles are being counted/ e. g., reviews, reports and so on are not considered original works/. SCIELO Consultancy Committee evaluates with the help of experts (peers).

- reviewing (peer-review) - the reviewing procedure has to be clearly indicated. When the journal is included into SCIELO, reviewing procedure has to be documented.

- editorial board has to be formed from national and international representatives, well known specialists. Journals, the editorial boards of which are formed from representatives of one institution or from representatives of one region or articles only from one institution or region are not included into SCIELO;

- $\quad$ periodicity - not less than 4 times per year.

Recently more than 12000 scientific journals are being counted in Brazil (Source: SCOPUS. http://www.scopus.com/search/form.url). It is posisible to observe a very rapid growth during the last decade.

Australia. Speaking about Melburn University as an example, the requirements for taking professor's position are very high. The candidate has to be achieved meaningful scientific achievements in his field not only on a national but also on an international level. He has to carry out original and innovative scientific researches including inventions and also to make a significant contribution into his institution's expansion. DEST (Australia's Department of Education, Science and Training) is taking care of evaluation. It is strictly defined what science publications are acknowledged (articles, books, conference material and so on). The most important requirement is peer-review and publication in a usual and e-form. The books have to be published in comercial publishing houses and by all means registrated in a fixed order (ISBN). As a matter of fact, seeking to get financing and also evaluate workers' qualification, 4types of 
works are evaluated: articles in refereed journals ; book sections; books; articles in international conference publications.

Romania. Science evaluation system in Romania is interesting for the fact that this country has had autoritarian regime for a long time, however, in recent years after changing conditions, it is seeking to develop science as rapid as possible. The question arises if Romanian science was in the right way after failure of communism in1989? They are seeking to invest into science as much as possible. Science production evaluation is carried out by National Council of Scientific Research and Higher Education (CNCSIS) - http://www.cncsis.ro/).

Primary criteria:

- Articles in ISI journals+ impact factor;

- Citation in ISI journals;

- Inventions;

- Contracts/ patents for products, technologies, studies

Secondary criteria:

- Articles in other journals;

- Models, prototipes, methodologies;

- Professional prestige;

- Membership in editorial boards of international publications;

- National science grants;

- $\mathrm{PhD}$.

SciSearch and Social SciSearch database are considered the main while evaluating science production. More articles in social science field are sought to be published in foreign journals. In the last decade such phenomenon can be noticed, however, there is no clear tendency. After evaluating current situation Romania needs: 15 years to catch up with Bulgaria, 30 years - with Poland, 60 - with Hungary (natural sciences, technologies and so on). In the case of social sciences: 50, 50, and 200. Romanians make a conclusion: science evaluation must be based on internationally acknowledged criteria. Science society (at least part of it ) is of the opinion that science is not only national affair (science is above national boundaries). A sharp discussion is taking place about mimicking of international evaluation norms. Over the last decade more than 500 journals appeared in the country. The main problem is that most of these journals do not use peer-review system and are not indexed in database. National science evaluation board orientates into international standards. In fact, scientometric parametres are adhered to.

\section{Conclusions}

No matter how much you dislike science production evaluation, it is inevitable and necessary. The state, allotting even rather poor financial resources for science, has to know if these means are being used rationally. On the other hand, internationally acknowledged norms (international standards) about science work evaluation, experting, indexing, usage and other exist. It is natural, that every country has its own peculiarities, which not necessarily directly match with international practice. However, countries should sensibly seek to harmonize national science work evaluation practice with the international one. Science production evaluation is important not only in the meaning of harmonization. Evaluation, on the whole, is a complicated and practical science theory problem. Creation of any this field evaluation methodics requires much responsibility. Evaluation has got not only financial - bureaucratic consequences, hasn't it? Evaluation affects both scientific staff and separate scientist's work, relations, moti- 
vation and so on. As you see from analysis, different countries distinguish themselves by their individuality, in the sense of science production evaluation. On the other hand, alongside with universally acknowledged evaluation systems, more widely and effectively are applied such systems as Google Scholar (http://scholar.google.com/). This system provides a search of scholarly literature across many disciplines and sources, including theses, books, abstracts and articles. Google Scholar, a freely available scientometric database, indexes academic papers from open access repositories and commercial sources, and also identifies referenced citations (Repanovici, 2010).Another system closely connected with the mentioned one is - Publish or Perish system (http://www.harzing.com/pop.htm). Publish or Perish is a software program that retrieves and analyzes academic citations. The free Publish or Perish software can be used as an analysis instrument for the impact of the research (Repanovici, 2010). More and more widely is used CiteSeerX system (http://citeseerx.ist.psu.edu/). CiteSeerX is a Scientific Literature Digital Library and Search Engine. CiteULike system as well (http://www.citeulike.org/). CiteULike is a free service for managing and discovering scholarly references. Finally, we can state that all measurements used in academic evaluations have some advantages and disadvantages. It is obligatory to find an appropriate combination of different systems, indicators and criteria.

As Zuleyma Tang-Martinez (2009) notices, higher science institutions both in USA and in other countries very rapidly implement a so-called corporation model, where everything is measured by concepts "clients", "consumers", "customers", "profit" and so on. Corporation machines (so-called universities, because according to a researcher, you can hardly call such institutions universities) keep turning. It means that profit is most important. It is completely understandable, that modern science is netlike, we say, "plane". Some artificial stages or requirements usually only disturb science development. However, the wish that concrete science achievements were evaluated, that positions were occupied by the people who are worth them is quite logical. A lot of countries seeking advance go along that way. Universities have to keep that understanding that firstly it is upon them to save and strengthen both activity quality and prestige and develop real but not demonstrative science.

\section{References}

Adler, R., Ewing, J., Taylor, P. (2008). Citation Statistics. A report from the International Mathematical Union (IMU) in cooperation with the International Council of Industrial and Applied Mathematics (ICIAM) and the Institute of Mathematical Statistics (IMS). Available on the Internet at: http://www.mathunion.org/fileadmin/IMU/Report/CitationStatistics.pdf (22/07/2010).

Anderson, M. S., Ronning, E. A., DeVries, R., Martinson, B. C. (2007). The Perverse Effects of Competition on Scientists' Work and Relationships. Science and Engineering Ethics, 13(4), p. 437-461.

Coordination for Higher Level Education Improvement (QUALIS/CAPES). Available on the internet at: http://www.capes.gov.br/avaliacao/qualis (22/07/2010).

Garfield, E. (1972). Citation analysis as a tool in journal evaluation. Science, 178, p. 471479.

Gómez-Sancho, J. M., Mancebón-Torrubia, M. J. (2009). The evaluation of scientific production: Towards a neutral impact factor. Scientometrics, Vol. 81, No. 2, p. 435-458.

Fanelli, D. (2009). How Many Scientists Fabricate and Falsify Research? A Systematic Review and Meta-Analysis of Survey Data. PLoS ONE, 4(5): e5738. doi:10.1371/journal.pone. 0005738 .

Lamanauskas, V. (2009). Mokslinès produkcijos vertinimas: originalumo paieškos ar paprastas kopijavimas. Švietimas: politika, vadyba, kokybė / Education Policy, Management and Quality, Nr. 3 (3), p. 4-9. 
Mokslo ir studijų institucijų moklso (meno) darbų vertinimo metodika. (2010). Lietuvos Respublikos švietimo ir mokslo ministro $2010 \mathrm{~m}$. liepos $10 \mathrm{~d}$. įsakymas Nr. V-1128. Vilnius. Prieiga per internetą: http://www.smm.lt/teisine_baze/docs/isakymai/2010-07-10-V-1128(1).doc $(22 / 07 / 2010)$.

Repanovici, A. (2010). Measuring the visibility of the University's scientific production using GoogleScholar, „Publish or Perish“ software and Scientometrics. In.: World Library and Information Congress: 76th IFLA General Conference and Assembly, Open access to knowledge promoting sustainable progress. Gothenburg. Available on the internet at: http://www.ifla.org/files/hq/papers/ifla76/155-repanovici-en.pdf (22/07/2010).

Toshev, B. (2008). Macrostability and Microinstabilities in the Scientific Process. Bulgarian Journal of Science and Education Policy (BJSEP), Vol. 2, No. 1, p. 5-12.

Vinkler, P. (2010). The evaluation of research by scientometric indicators. Oxford: Chandos Publishing, $313 \mathrm{p}$.

Zuleyma Tang-Martinez (2002). Higher Education and the Corporate Paradigm: the Students are the Losers. Workplace: a Journal for Academic Labor. Available on the internet at: http://louisville.edu/journal/workplace/wp42.html (22/12/2009).

\section{Acknowledgement}

The author is thankful to all colleagues for participating in the open discussion on this relevant topic: Agnaldo Arroio (Brazil), Martin Bilek (Czech Republic), Bulent Cavas (Turkey), David Clarke (Australia), Kuo-Hung Huang (Taiwan), Costin Pribeanu (Romania), Suan Young (Malaysia), Borislav Toshev (Bulgaria). All ideas and comments were useful. Thanks also go to Ilona Ratkevičienè for the language revision.

\section{Note}

This is a revised and expanded version of a international scientific conference paper in Švietimas: politika, vadyba, kokybe / Education Policy, Management and Quality. The paper was recommended for republication by the conference scientific committee.

The reference for the Conference version is:

Lamanauskas, V. (2010). Topical Scientific Production and Scientific Qualification Evaluation Questions. In. The Pedagogy of the Higher Education: Methodology, Theory, Technology (Proceedings of the 4th International Scientific Conference“, Rivne, Ukraine, October 14-15, 2010), Vol. 3. Rivne: International University of Economics and Humanities named after academician Stepan Demianchuk, p. 42-53.

Received 22 November 2010; accepted 29 January 2011

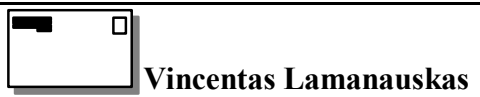

Professor, Natural Science Education Research Centre, Siauliai University, P.Visinskio Street 25, LT-76351 Siauliai, Lithuania

E-mail: v.lamanauskas@ef.su.lt

Website: http://www.lamanauskas.projektas.lt/ 